\title{
Gebe okulu eğitimcileri ve emzirme hemşirelerine verilen Watson'ın İnsan Bakım Kuramına temellendirilmiş emzirme eğitiminin etkinliğinin değerlendirilmesi
}

\author{
Evaluation of effectiveness of breastfeeding in-service education based on Watson's \\ Theory of Human Caring given to childbirth, breastfeeding educator nurses and midwives
}

\author{
Gamze Durmazoğlu, Özlem Çiçek, Serap Yaşaroğlu Toksoy, Hülya Okumuş, Merlinda Aluş Tokat
}

\section{Özet}

Amaç: Gebe okulu eğitimcileri ve emzirme hemşirelerine verilen Watson'ın İnsan Bakım Kuramına (IBKK) temellendirilmiş emzirme eğitiminin etkinliğinin değerlendirilmesidir.

Gereç ve yöntem: Gebe okulu eğitimcileri ve emzirme hemşirelerine yönelik Watson'ın İBK'na temellendirilmiş bir yenilenme kursu düzenlenmiştir. Kursa katılan ebe ve hemşirelerin yürüttükleri emzirme eğitimlerine ilişkin bilgi ve görüşleri kurs öncesi ve sonrasında değerlendirilmiştir. Çalışma kantitatif ve kalitatif verileri içeren karma tipte bir araştırmadır. Kurs programına 36 gebe okulu eğitimcisi/emzirme hemşiresi dahil edilmiştir. Verilerin toplanmasında; "Kurs Öncesi ve Sonrası Değerlendirme Formları" kullanılmıştır. Veriler SPSS 22 programında değerlendirilmiştir; sosyo-demografik ve mesleki özellikler için sayı ve yüzde kullanılmıştır. Kurs öncesi ve sonrası bilgi düzeyindeki puan artışı bağımlı gruplarda t testi ile analiz edilmiştir. Kalitatif verilerin analizi için tematik analiz yapılmıştır.

Bulgular: Eğitimci hemşire/ebelerin yaş ortalaması 43,5 olup, ortalama 3,7 yıldır ise emzirme eğitimi yaptıkları saptanmıştır. Kurs sonrası katılımcıların çoğunlukla video gösterimi/role-play/meditasyon $(\% 44,1)$ ve sunum $(\% 24,5)$ yöntemlerini eğitimlerinde kullanmayı tercih etmekle birlikte, yenilikçi olarak Watson'ın İnsan Bakım Kuramında temel aldığı sevgi temelli yaklaşımları $(\% 19,6)$ da kullanmayı planladıkları belirlenmiştir. Kurs katılımcılarının emzirme eğitimlerinde Watson'ın iyileştirme süreçlerinden; inanç-umut, olumlu ve olumsuz duyguların ifadesi, öğretme-öğrenme, iyileşme çevresi, gereksinimlere yardım faktörlerine daha fazla önem verecekleri saptanmıştır.

Sonuç: Watson'ın İBK'na temellendirilmiş emzirme eğitiminin katılımcıların farkındalığını arttırdığı, eğitim programlarına yenilikçi eğitim yöntemlerini ve İBK'nı dâhil etmeyi planladıkları belirlenmiştir.

Anahtar kelimeler: Emzirme, hizmet içi eğitim, hemşireler, ebeler, insan bakım kuramı.

Durmazoğlu G, Çiçek Ö, Yaşaroğlu Toksoy S, Okumuş H, Aluş Tokat M. Gebe okulu eğitimcileri ve emzirme hemşirelerine verilen Watson'ın İnsan Bakım Kuramına temellendirilmiş emzirme eğitiminin etkinliğinin değerlendirilmesi. Pam Tıp Derg 2021;14:79-88.

\begin{abstract}
Purpose: To evaluate effectiveness of breastfeeding education based on Watson's Human Caring Theory (HCT) given refreshment course for childbirth educator/breastfeeding consultant.

Materials and methods: Breastfeeding continuing education program was based on Watson's HCT. Before/ after course, evaluations of participants regarding their education programme were examined. Course goals were evaluated with using pre-and post-test. It is mixed type qualitative, quantitative research. 36 pregnant school educators / breastfeeding nurses were included in the course program. In collecting data; "Pre-Post Course Evaluation Forms" were used. Data were evaluated in SPSS-22 program, numbers and percentages were used for socio-demographic and professional characteristics. To analyze the increase in knowledge level, paired samples t-test was used. Thematic analysis was used for qualitative data.

Results: The average age of participants is 43.5, it was determined that they had been breastfeeding training for 3.7 years. After course, it was determined that participants mostly preferred to use video display/role-play/ meditation (44.1\%) and presentation (24.5\%) methods, and they also plan to use Watson's approaches (19.6\%)
\end{abstract}

Gamze Durmazoğlu, Uzm. Hemşire, S.B.Ü. İzmir Bozyaka Eğitim ve Araştırma Hastanesi, İzmir, Türkiye, e-posta: gmz2805@hotmail.com (orcid.org/0000 00030855 6030) (Sorumlu Yazar)

Özlem Çiçek, Dr. Öğr. Üyesi, İzmir Bakırçay Üniversitesi Sağlık Bilimleri Fakültesi, Kadın Sağlığı ve Hastalıkları Hemşireliği, ozlem.cicek@ bakircay.edu.tr (orcid.org/0000 00015124 5719)

Serap Yaşaroğlu Toksoy, Hemşire, İmir İ Sağlık Müdürlüğü, İzmir, Türkiye, e-posta: serap.toksoy@hotmail.com (orcid.org/0000 00020356 2389)

Hülya Okumuş, Prof. Dr. Dokuz Eylül Üniversitesi Hemşirelik Fakültesi Doğum ve Kadın Hastalıkları Hemşireliği, İzmir, Türkiye, e-posta: hulya3. okumus@gmail.com (orcid.org/0000 00020979 4981)

Merlinda Aluş Tokat, Doç. Dr. Dokuz Eylül Üniversitesi Hemşirelik Fakültesi Doğum ve Kadın Hastalıkları Hemşireliği İzmir, Türkiye, e-posta: merlinda_alus@yahoo.com (orcid.org/0000 00025899 0524) 
innovatively. It was determined that participants pointed out more importance to instillation of faith-hope, expression, promotion and acceptance of expression of positive-negative feelings, promotion of interpersonal teaching-learning, provision for supportive, protective, and/or corrective mental, physical, sociocultural, and spiritual environment, and assistance with gratification of human needs.

Conclusion: Breastfeeding education program based on Watson's HCT has increased awareness of participants. It has been determined that participants will include innovative education method, Human Care Theories carative factors in their programs.

Keywords: Breastfeeding, in-service education, nurses, midwives, theory of human caring.

Durmazoglu G, Cicek O, Yasaroglu Toksoy S, Okumuş H, Aluş Tokat M. Evaluation of effectiveness of breastfeeding in-service education based on Watson's Theory of Human Caring given to childbirth, breastfeeding educator nurses and midwives. Pam Med J 2021;14:79-88.

\section{Giriş}

Emzirme, anne ve bebekte uzun vadede gelişebilecek bazı kanser ve kronik hastalıkların riskini azaltarak onları yaşamları boyunca korur [1]. Bu nedenle emzirme, hem anne hem de bebekler için en faydalı beslenme yoludur. Türkiye Nüfus ve Sağlık Araştırması (TNSA) 2018 verilerine göre ülkemizde 6 aydan küçük çocukların \%41'i sadece anne sütüyle beslenmektedir. Ancak sadece anne sütü alan çocukların oranı yaşla birlikte hızla azalmaktadır; 0-1 aylık çocuklar arasında bu oran \%59 iken 4-5 aylık çocuklar arasında \%14'e düşmektedir [2].

Emzirmede başarıya ulaşmak için annelerin ve eşlerinin emzirme ve anne sütü hakkında bilgilendirilmeleri gereklidir. Emzirme eğitimleri; klinik eğitimler, evde ziyaret programları, akran eğitim programları gibi farklı şekillerde uygulanabilmektedir. Emzirme eğitimleri genellikle belirli bir amaç ve kitleyi hedef alarak önceden belirlenmiş program çerçevesinde yürütülür [3].

Emzirme eğitimlerinde emzirme davranışlarını öngörmede etkili bir teorik çerçeve kullanımı, anne sütü ile beslenmeyi teşvik edici girişimlere rehberlik etmek için yararlı olacaktır. Jean Watson "İnsan Bakım Kuramı"nda (IBKK) bakım davranışlarını belirlemiş ve bakımda sevgiyi temel almıştır. Watson girişim kelimesini mekanik bulduğu için "iyileştirici faktörler" kavramını geliştirmiştir. Watson, iyileştirici faktörleri "iyileştirilme süreçleri" ile birlikte açıklamaktadır (Tablo 1). Watson'ın İnsan Bakım Kuramı'nda açıkladığı "karatif/iyileştirme süreçleri" hemşireliğin özünü oluşturmaktadır [4]. Watson'a göre; dikkatli dinleme, göz teması kurma, dürüstlük, dokunma, duyarlılık, saygılı olma, güven verme, fiziksel ve zihinsel hazır bulunma, duygusal olarak açık ve ulaşılabilir olma, birey merkezli olma, bilgi verme, kültürel farklılıkları dikkate alma, bakımda temel alınması gereken konulardır [5-7]. Watson'ın modeline dayalı bakım, yaşamdaki anlam duygusunu arttırır [8, 9]. Bu nedenlerle emzirme eğitimlerinde sevgi temelli yaklaşımların kullanılması annelerin emzirme öz-yeterlilik duygusunu arttıracaktır. Bununla birlikte annelerin stres ile başetme mekanizmaları güçlenecek ve böylece emzirme oranlarının artması sağlanacaktır.

Uygulama alanlarında görevli hemşire ya da ebelerin hemşirelik kuramları ve farklı eğitim yöntemleri hakkında bilgilendirilmeleri önemlidir. Çünkü emziren annelerle en fazla etkileşimde bulunan hemşire ve ebelerin sürekli eğitimlerinin güncellenmesiyle emzirme problemlerinin çözümü kolaylaşacak ve emzirme oranlarının artmasına katkı sağlayacağı düşünülmüştür. Bu alandaki literatür incelendiğinde Watson'ın Insan Bakım Kuramına temellendirilmiş emzirme eğitiminin etkinliğine yönelik yapılmış herhangi bir çalışmaya rastlanmamıştır.

Bu çalışmanın amacı; gebe okulu eğitimcileri ve emzirme hemşirelerine verilen Watson'ın "Insan Bakım Kuram"ına temellendirilmiş emzirme eğitiminin etkinliğini incelemektir.

\section{Gereç ve yöntem}

Çalışma; emziren annelere en fazla bakım sunan ve İzmir ili kamu hastanelerinde emzirme eğitimi veren, kursa katılmayı kabul eden gebe okulu eğitimcileri ve emzirme hemşireleri ile yapılmıştır. Eğitime toplam 36 ebe/hemşire katılmış olup, tüm katıımcılar çalışmanın örneklemini oluşturmuştur. Eğitim programının içeriği güncel emzirme literatürü ve Watson'ın 
Tablo 1. Watson iyileştirici faktörleri ve iyileştirme süreçleri $[4,9]$

\begin{tabular}{|c|c|}
\hline İyileştirici Faktörler & İyileştirme süreçleri (Hemşirelik Yaklaşımları) \\
\hline $\begin{array}{l}\text { 1.İnsancıllık-adanmışlık değerler } \\
\text { sistemi }\end{array}$ & $\begin{array}{l}\text { İnsancıllık ve adanmışlık gibi değerleri benimseme, kendine ve bireye, sevgiyle, } \\
\text { şefkatle yaklaşma }\end{array}$ \\
\hline 2. İnanç-umut & $\begin{array}{l}\text { Bireye inanç ve umudu aşılama (İnançlarını ve öznel yaşam dünyasını kabul } \\
\text { ederek) }\end{array}$ \\
\hline 3. Duyarlılık & Bireysel inanç ve uygulamaları geliştirerek, kendine ve bireylere duyarlı olma \\
\hline 4. Yardım-güven ilişkisi & Yardım edici-güven verici bakım ilişkisi geliştirme (kalpten gelerek) \\
\hline $\begin{array}{l}\text { 5. Olumlu ve olumsuz duyguların } \\
\text { ifadesi }\end{array}$ & $\begin{array}{l}\text { İnsanların öykülerini içtenlikle dinleyerek olumlu ve olumsuz duyguların ifade } \\
\text { edilmesini sağlama }\end{array}$ \\
\hline 6. Problem çözme & $\begin{array}{l}\text { Bakıma karar vermek için hasta, ailesi ve toplum yararına yaratıcı, bilimsel } \\
\text { problem çözme yöntemlerini kullanma }\end{array}$ \\
\hline 7. Öğretme-öğrenme & Bireysel gereksinimlere ve anlama stiline uygun öğrenme ve öğretmeyi sağlama \\
\hline 8. İyileşme çevresi & $\begin{array}{l}\text { Fiziksel, duygusal ve manevi anlamda konforlu, güzel, huzurlu bir çevre } \\
\text { oluşturma }\end{array}$ \\
\hline 9. Gereksinimlere yardım & Temel fiziksel, duygusal ve ruhsal gereksinimlere yardımcı olma \\
\hline $\begin{array}{l}\text { 10. Manevi gizemlere, ölüm ve yaşamın } \\
\text { varlıksal boyutlarına açık olma }\end{array}$ & Yaşamı anlamlandırmak için rüya, hayal, sezgi, efsane vb. şeylerin rolleri \\
\hline
\end{tabular}

İnsan Bakım Kuramı'na temellendirilmiştir. Kurs süresi sekiz saat olup interaktif eğitim yöntemleri (tartışma, beyin fırtınası, emzirme danışmanlığında sık karşılaşılan vakalar üzerinden sorun çözme yaklaşımlarının oluşturulduğu grup çalışmaları, rol-play'ler) kullanılmıştır. Programda katılımcılara Watson'ın İnsan Bakım Kuramı tanıtımış, kuramın emzirme davranışı ve emzirme eğitimcilerinin eğitim becerileri üzerine olumlu etkileri, güncel kanıtlar ve teknoloji ile kuram kullanımının nasıl birleşebileceği üzerine bilgiler verilmiştir. Kurs öncesi ve sonrası katılımcıların annelere yaptıkları eğitimlere ilişkin değerlendirmeleri incelenmiştir.

Karma (niteliksel ve niceliksel) tipte bir araştırmadır.

Verilerin toplanmasında; eğitimciler tarafından eğitimin etkinliğini değerlendirmek için literatür doğrultusunda hazırlanan Kurs Öncesi ve Sonrası Değerlendirme Formları kullanılmıştır. Kurs öncesi ve sonrası değerlendirme formları, katılımcıların sosyodemografik özellikleri, emzirme eğitimlerinde kullandıkları yöntemlerl ve sık karşılaşılan emzirme problemlerine ilişkin 3 soru ile Watson'ın iyileştirme faktörlerine ilişkin görüş ve uygulamalarını içeren 10 maddelik likert tipteki sorudan oluşmaktadır. Değerlendirme formları daha önceki literatür ve konusunda uzman üç öğretim üyesinden uzman görüşü alınarak yeniden düzenlenmiştir.

Verilerin analizi için SPSS 22 (Statistical Package for the Social Science) programı kullanılmıştır. Sosyo-demografik verilerin analizi sayı ve yüzde ile hesaplanmıştır. Kurs öncesi ve sonrası bilgi düzeyindeki puan artışı dağılımı normal olduğundan parametrik testlerden bağımlı gruplarda t testi ile analiz edilmiştir. Katılımcıların "Emzirme Güçlüğü Yaşayan Annelere Nasıl Yaklaşımda Bulunacaklarına" ilişkin yazdıkları cevaplar nitel araştırma yöntemlerinden olan döküman incelemesi yöntemi ile incelenmiştir. Elde edilen nitel verilerin analizi için içerik analizi yöntemlerinden tümden gelim ve tematik analiz yöntemi kullanılmıştır. Tematik analiz iki bağımsız araştırmacı tarafından yapılmıştır, daha sonra nitel analiz konusunda deneyimli uzman bir hemşire tarafından doğrulanarak geçerlik ve güvenirliği için üçgenleme (triangulasyon) yöntemi kullanılmıştır. Açık uçlu sorulara verilen yanıtlar eğitimcilerin ifadelerinde geçen kavramlara göre kodlanmış ve Watson'ın iyileştirme süreçlerine dayalı olarak tematik analiz yapılmıştır.

Araştırma için Dokuz Eylül Üniversitesi Girişimsel Olmayan Klinik Araştırmalar Etik 
Kurulu'ndan izni alınmıştır. Düzenlenen kurs programı İzmir İ Sağlık Müdürlüğü işbirliği ile yapılmış olup, kurs katılımcıları değerlendirme formların doldurmaları için bilgilendirilmiş ve onamları alınmıştır.

\section{Bulgular}

Araştırmanın bulguları niceliksel ve niteliksel bulgular olarak ayrı ayrı verilmiştir.

\section{Niceliksel bulgular}

Çalışma sonucunda elde edilen bulgulara göre; eğitimci hemşire/ebelerin yaş ortalaması 43,47'dir ve ortalama 3,77 yıldır emzirme eğitimcisi olarak çalışmaktadırlar. Kurs katılımcılarının \%86,1'inin 15 yıl veya daha fazla süredir çalıştıkları saptanmıştır. Hemşire/ ebelerin çoğunun $(\% 83,3)$ emzirme eğitimi konusunda eğitim aldıkları belirlenmiştir (Tablo 2).

Eğitimcilerin eğitim verdikleri post-partum dönemdeki kadınlarda en sık karşılaştıkları emzirme probleminin "süt yetersizliği algısı" olduğu saptanmıştır $(\% 33,4)$ (Tablo 3$)$.

Yapılan analizlerde; kurs katılımcılarının $\% 70$ 'inin eğitimlerinde sunum yöntemini kullandığı belirlenmiştir. Kurs sonrası katılımcılara kursta öğrendiklerine göre hangi eğitim yöntemlerini kullanmayı düşündükleri sorulmuştur. Eğitimcilerin çoğunlukla video gösterimi/rol- play/meditasyon $(\% 44,1)$ ve sunum $(\% 24,5)$ yöntemlerini eğitimlerinde kullanmayı tercih etmekle birlikte, yenilikçi olarak Watson'ın İnsan Bakım Kuramında temel aldığı sevgi temelli yaklaşımları $(\% 19,6)$ da kullanmayı planladıkları belirlenmiştir (Tablo 4).

Kurs katılımcılarından kurs öncesi ve sonrası Watson'ın İyileştirici Faktörlerinin emzirme eğitimlerinde kullanılmasının önemini puanlamaları istenmiştir. Katılımcılar her bir maddeye 1-5 arasında puan vermişlerdir. İnanç-umut, olumlu ve olumsuz duyguların ifadesi, öğretme-öğrenme, iyileşme çevresi, gereksinimlere yardım, manevi gizemlere ve ölüm ve yaşamın varlıksal boyutlarına açık olma faktörlerinin kullanılması gerekliliğine verilen puan ortalamaları kurs sonrası öncesine göre istatistiksel olarak anlamlı derecede artmıştır. Duyarlılık, yardım-güven ilişkisi ve problem çözme faktörlerinde kurs sonrasında puan artışı olmakla birlikte istatiksel düzeyde kurs öncesine göre önemli bir fark saptanmamıştır. Katılımcıların, kurs sonrası "iyileştirici faktörlerin emzirme eğitimlerinde kullanılması gerekliliğine verdikleri puan ortalaması kurs öncesine göre istatistiksel olarak anlamlı derecede daha yüksek bulunmuştur (Tablo 5).

Tablo 2. Katıımcıların sosyo-demografik ve mesleki özellikleri (n:36)

\begin{tabular}{|c|c|c|}
\hline Sosyo-Demografik ve Mesleki Özellikler & \multicolumn{2}{|c|}{$(\overline{\mathbf{X}} \pm \mathrm{SS})$} \\
\hline Yaş & \multicolumn{2}{|c|}{$43,47 \pm 5,45$} \\
\hline Emzirme Eğitimcisi olarak & \multicolumn{2}{|c|}{$3,77 \pm 2,55$} \\
\hline \multicolumn{3}{|l|}{ Çalışma Yılı ( $\bar{x} \pm S S)$} \\
\hline & $\mathbf{n}$ & $\%$ \\
\hline \multicolumn{3}{|l|}{ Eğitim Durumu } \\
\hline Lisans ve $\downarrow$ & 3 & 8,3 \\
\hline Lisans ve $\uparrow$ & 33 & 91,7 \\
\hline \multicolumn{3}{|l|}{ Mesleki Deneyim Yılı } \\
\hline $10-15$ Y Il & 5 & 13,9 \\
\hline 15 Yıl ve Üstü & 31 & 86,1 \\
\hline \multicolumn{3}{|c|}{ Emzirme Eğitimciliğine İlişkin Eğitim Alma Durumu } \\
\hline Alan & 30 & 83,3 \\
\hline Almayan & 6 & 16,7 \\
\hline
\end{tabular}

X̄:ortalama; SS: standart sapma; n: sayı; \%: yüzde; $\downarrow$ : altı; $\uparrow$ : üstü 
Tablo 3. Katıııcıların emziren annelerde en sık karşılaştıkları emzirme problemleri (n:36)

\begin{tabular}{lcc}
\hline Sık Karşılaşılan Emzirme Problemleri & $\mathbf{n}$ & $\%$ \\
\hline Süt Yetersizliği Algısı & 12 & 33,5 \\
Meme Başı Problemleri & 7 & 19,4 \\
Destek Eksikliği & 7 & 19,4 \\
Memeyi Kavrayamama & 4 & 11,1 \\
Bebeğin Anne Yanında Olmaması & 3 & 8,3 \\
Özgüven Eksikliği & 3 & 8,3 \\
\hline
\end{tabular}

Tablo 4. . Kurs öncesi ve sonrası tercih edilen emzirme eğitim yöntemlerinin karşılaştırması

\begin{tabular}{|c|c|c|c|c|c|}
\hline $\begin{array}{l}\text { Kurs Öncesi Kullanılan Eğitim } \\
\text { Yöntemleri }\end{array}$ & $\mathrm{n}^{*}$ & $\%$ & $\begin{array}{l}\text { Kurs Sonrası Kullanılması } \\
\text { Planlanan Eğitim Yöntemleri }\end{array}$ & $\mathbf{n}^{*}$ & $\%$ \\
\hline Sunum & 35 & 70,0 & $\begin{array}{l}\text { Video Gösterimi/ Rol- Play/ } \\
\text { Meditasyon }\end{array}$ & 63 & 44,1 \\
\hline \multicolumn{6}{|c|}{ Video/Meme Modeli/ Afiş/Broşür ile Gösterim } \\
\hline & 12 & 24,0 & Sunum & 35 & 24,5 \\
\hline \multicolumn{6}{|c|}{ Emzirme Destek Sistemi/ Doğum Sonu İzlem } \\
\hline & & & Sevgi Temelli Yaklaşım (İBK) & 28 & 19,6 \\
\hline & 3 & 6,0 & & & \\
\hline & & & Teknoloji Kullanımı & 10 & 7,0 \\
\hline & & & Eş Eğitimi & 7 & 4,8 \\
\hline
\end{tabular}

* Birden fazla yöntem işaretlendiği için n katlanmıştır

Tablo 5. Katılımcıların kurs öncesi ve sonrası emzirme eğitiminde Watson'ın iyileştirici faktörlerinin önemine ilişkin verdikleri puan ortalamalarının karşılaştırılması (n:36)

\begin{tabular}{lllll}
\hline & Kurs Öncesi & Kurs Sonrası & \multicolumn{2}{l}{ Bağımlı Gruplarda } \\
\hline Watson'ın İyileştirici Faktörleri & $\overline{\mathrm{x}} \pm \mathrm{SS}$ & $\overline{\mathrm{x}} \pm \mathrm{SS}$ & $\mathrm{t}$ & $\mathrm{p}$ \\
\hline Inanç-umut & $4,86 \pm 0,35$ & $4,97 \pm 0,16$ & $-2,09$ & $0,044^{*}$ \\
Duyarlıık & $4,91 \pm 0,28$ & $4,97 \pm 0,16$ & $-1,43$ & 0,160 \\
Yardım-güven ilişkisi & $4,91 \pm 0,28$ & $5,0 \pm 0,00$ & $-1,78$ & 0,083 \\
Olumlu ve olumsuz duyguların & $4,88 \pm 0,31$ & $5,0 \pm 0,00$ & $-2,09$ & $0,044^{*}$ \\
$\begin{array}{l}\text { ifadesi } \\
\text { Problem çözme }\end{array}$ & $4,94 \pm 0,23$ & $5,0 \pm 0,00$ & $-1,43$ & 0,160 \\
Öğretme-öğrenme & $4,83 \pm 0,37$ & $5,0 \pm 0,00$ & $-2,64$ & $0,012^{*}$ \\
Iyileşme çevresi & $4,80 \pm 0,40$ & $5,0 \pm 0,00$ & $-2,90$ & $0,006^{*}$ \\
Gereksinimlere yardım & $4,83 \pm 0,37$ & $5,0 \pm 0,00$ & $-2,64$ & $0,012^{*}$ \\
\hline
\end{tabular}

$\overline{\mathrm{X}}$ : ortalama; SS: standart sapma; $\mathrm{t}$ t testi; $p$ : anlamlılık değeri

* $p<0,05$ 


\section{Niteliksel bulgular}

Açık uçlu sorulara verilen yanıtlar; katılımcıların "Emzirme Güçlüğü Yaşayan Annelere Nasıl Yaklaşımda Bulunacaklarına" ilişkin yazdıkları ifadelerde geçen kavramlara göre kodlanmıştır. Ardından Watson'ın iyileştirici faktörleri "tema" olarak gruplandırılmış ve tematik analiz yapılmıştır. İyileştirici faktörlerden yalnızca konuyla ilişkili bulunan faktörler kullanılmıştır.

\section{İyileştirici faktör (IF) 2. inanç-umut}

"Olumlu davranışları övme, destekleme" "Gerekmiyorsa olumsuz durumlardan söz etmeme", "Sorun oluşmadan sorunu konuşup bilinçaltını olumsuz etkilememe", "Kendilerine inanmalarını sağlama", "Emzirme umudunu destekleme", "Öz-yeterliliğini destekleme", "Motivasyonu artırma".

\section{IF 3. Duyarlılık}

"Ekip olarak sevgi temelli yaklaşımı benimseme", "İ̧̧ yoğunluğu olsa bile her anneye emzirme konusunda zaman ayırma".

\section{if 4. Yardım-güven ilişkisi}

"Anneyi emzirme pozisyonu konusunda zorlamama", "Yardım edici davranma", "Güven ilişkisi kurma", "Sevgi diliyle anlatmak", "Daha ilgili ve şefkatli yaklaşım", "Karşılıklı sevgi ve saygı çerçevesinde iletişim", "Samimi iletişim".

\section{if 5. Olumlu ve olumsuz duyguların ifadesi}

"Anneyi aktif dinleme".

\section{if 6. Problem çözme}

"Soruna yönelik birlikte çözüm üretme", "Doğal ve sevgi dolu bir iletişimle sorunları çözme".

\section{IF 7. Öğretme-öğrenme}

"Bireysel özelliklerine göre eğitim verme", "İhtiyaç duydukları bilgileri verme", "Gereksiz bilgiden kaçınma, az ve öz bilgi verme", "Eğitimin süresinden çok kalitesine önem verme", "Eğitim materyali geliştirme/çoğaltma".

\section{IF 8. İyileşme çevresi}

"Olumlu eğitim ortamı oluşturma", "Eğitim ortamında görsel materyaller kullanma", "Çevreyi anneye göre düzenleme".

\section{IF 9. Gereksinimlere yardım}

"Aile desteğine intiyacı varsa bu gereksinimini belirleme", "Destek alacağı yerleri tanıtma", "Eşleri de eğitime alma".

\section{Tartışma}

\section{Sık karşılaşılan emzirme problemleri}

Doğum sonu dönemde anneler birçok emzirme problemi yaşayabilmektedirler. Çalışmamızda katıımcıların doğum sonu en sık süt yetersizliği algısı problemi ile karşılaştıkları belirlenmiştir (Tablo 3). Karaçam ve Sağlık'ın [10] yaptıkları sistematik derlemede; bizim çalışmamıza benzer olarak annelerin çoğunlukla yaşadıkları problemlerden birinin süt yetersizliği/ süt yetersizliği endişesi olduğu belirlenmiştir. Yapılan başka bir çalışmada ise annelerin çoğunlukla bebeğin memeyi kavrayamaması ve meme ucu problemleri yaşadıkları saptanmıştır. Yaşanan sorunlarla ilişkili faktörler; primipar olma, öz-yeterlilik eksikliği ve emzirme bilgisinin az olması olarak bulunmuştur [11].

\section{Emzirme eğitim yöntemleri}

Çalışmamızda katılımcıların çoğunlukla sunum yöntemini kullandıkları, eğitim sonrası sunum yöntemine ek olarak video gösterimi, rolplay ve meditasyon yöntemlerini de kullanmayı planladıkları saptanmıştır (Tablo 4).

Türkiye'deki hastanelerde verilen emzirme eğitim programları (ya da gebe okulu eğitimleri kapsamında verilen emzirme eğitimleri) incelendiğinde çoğunlukla sunum yönteminin kullanıldığı saptanmıştır. Fakat Dünya'da ve ülkemizde emzirme eğitimlerinde bilgiye ulaşımı kolaylaştırdığı için teknolojiye dayalı yöntemler de kullanılmaya başlanmıştır.

Kellams ve ark'nın [12] Amerika Birleşik Devletleri'nde düşük gelir düzeyine sahip bir toplumda yürüttükleri çalışmada, emzirme eğitimlerinde video kullanımının emzirmeye başlama ve tam emzirme oranlarına etkisini araştırılmıştır. Emzirme eğitiminde video kullanımının emzirme desteğine olan ihtiyacı azalttığı belirlenmiştir. Hindistan'da yapılan bir çalışmada, doğum sonrası tam emzirmeyi teşvik etmek için video tabanlı bir sağlık eğitim programı kullanılmıştır. Video, tam emzirmenin avantajları, doğru emzirme pozisyonları ve bağlanma, sık görülen emzirme sorunları, formül mama ve biberonla beslenmenin dezavantajları 
hakkında bilgileri içermiştir. Tam emzirmeyi teşvik etmek için uygun animasyonlar, röportajlar, rolplayler, ses ve video klipleri bu video tabanlı sağlık eğitimi programına dâhil edilmiştir. Video, doğum sonu servisinde annelerin bulundukları odalardaki televizyonlarda günde üç kez yayınlanmıştır. Doğum sonu izlemler ilk 6 ay devam etmiştir. Video yöntemiyle verilen emzirme eğitiminin tam emzirme oranlarını artırdığı saptanmıştır [13]. Ülkemizde yapılan bir çalışmada bebeği yenidoğan yoğun bakım ünitesinde olan annelere video izletme yoluyla verilen anne sütü ve hijyen eğitimi sonrası annelerin memnuniyetleri araştırılmıştır. Annelerin yaklaşık tamamının video izleme yoluyla bilgilerinin arttığı $(\% 97,77)$ ve eğitimden memnun kaldıkları $(\% 97,96)$ belirlenmiştir [14]. Bu çalışmadaki kurs katılımcıları da kurs sonrası annelere yapacakları eğitimlerde "rolplay" yöntemini kullanmayı planladıklarını belirtmişlerdir (Tablo 4).

Öğrenme stili kişiliğe, sosyokültürel durum ve yaşam deneyimlerine göre değişmektedir. Bazı bireyler dinleme ile öğrenirken bazıları ise yaşayarak, hissederek öğrenirler [15]. $\mathrm{Bu}$ nedenle emzirme eğitimlerinde rol-play eğitim yöntemine de yer verilmesi annelerin öğrenmelerini olumlu yönde etkileyecektir. İran'da emzirmeyi rol-play yoluyla öğretmenin emzirme öz-yeterliliği üzerindeki etkilerini araştırmak amacıyla yapılan çalışmada annelere gebeliğin 36. haftasında 90 dakikalık emzirme eğitimi verilmiştir. Öncelikle araştırmacılar, emziren anne, büyükanne, teyze ve eğitimci rolleri için bir senaryo hazırlamışlardır. Rol-play konuları; doğru emzirme teknikleri, emzirme problemleri, annenin bebeğin beslenmesi hakkındaki endişeleri ve emzirme sırasında annenin özel ihtiyaçları olarak belirlenmiştir. Eğitim öncesi ve sonrası, doğumdan bir hafta ve bir ay sonra öz-yeterlilik değerlendirmeleri yapılmıştır. Rol-play yoluyla verilen emzirme eğitiminin annelerin öz-yeterliliğini ve tam emzirme oranlarını artırdığı belirlenmiştir [16]. $\mathrm{Bu}$ bilgilere göre annelerin yaşadıkları benzer sorunların çözümünde oyunlaştırma yoluyla öğrenmenin etkili olduğu sonucuna ulaşılabilir.

\begin{tabular}{lccc} 
Katılımcılar, & yapacakları & \multicolumn{2}{c}{ eğitimlerde } \\
"meditasyon"” & yöntemini & \multicolumn{2}{c}{ kullanmayı } \\
planladıklarını & belirtmişlerdir & (Tablo & 4 ). \\
Meditasyon ile bilişsel, fizyolojik & ve nörolojik \\
işleyişte artışlar & gözlenmektedir & [17]. Bu
\end{tabular}

nedenle eğitim sırasında meditasyon kullanımı annelerin algılarını artırarak öğrenme süreçlerini kolaylaştırabilir. Ayrıca emzirme döneminde meditasyon yapan annelerin fizyolojik ve psikolojik stresörlerle başa çıkabilecekleri, emzirmeyi başlama ve sürdürme oranlarının artacağı düşünülmektedir [18]. İspanya'da 26 anne ile yapılan pilot çalışmada 10 dakika süren 2 ya da 3 seanslık meditasyonlar yapılmış ve deney grubundaki annelerin öz-yeterliliği kontrol grubuna göre daha yüksek bulunmuştur. Ayrıca annelerin emzirme sürecinde daha az kaygı, stres ve psikolojik sıkıntı yaşadıkları belirlenmiştir. Sonuçlar, perinatal ve postpartum dönemlerde farkındalığa dayalı müdahalenin emzirme üzerine olumlu etkilerinin olacağını desteklemektedir [19]. Bu nedenle emzirme eğitimlerinde meditasyon yöntemlerinin kullanıımasının yararlı olacağı düşünülmektedir.

Watson'a göre; sevgi en önemli iyileşme kaynağıdır. Emzirmenin başlatılıp sürdürülmesinde hormonların etkisi büyüktür. Emzirme sürecinde rolü büyük olan hormonal dengenin en önemli düzenleyicilerinden biri de sevgidir. Bu nedenle emzirme eğitimlerinde sevgi temelli yaklaşımların temel alındığı Watson'ın İBK'nın kullanılmasının emzirme başarısını artıracağı ön görülmektedir.

Yenilikçi olarak Watson'ın İnsan Bakım Kuramında temel aldığı sevgi temelliyaklaşımları her 5 katılımcıdan birinin kullanmayı planladığı belirlenmiştir (Tablo 4). Bu yaklaşım kurs öncesi değerlendirme formunda hiç belirtilmeyen bir yaklaşım iken, kurs sonrası ölçümde "öğrenilmiş bir kavram" olarak görülmüştür. Bu bulgu kursun hedefine/amacına ulaştığını göstermesi nedeniyle oldukça önemli bir sonuç olarak değerlendirilebilir.

\section{Emzirme eğitiminde Watson'ın iyileştirici faktörleri}

Watson'ın İyileştirici Faktörlerindeki kavramların tematik analizi sonucunda; katıımcıların emzirme eğitimlerinde Watson'ın iyileştirme süreçlerinden; inanç-umut, olumlu ve olumsuz duyguların ifadesi, öğretmeöğrenme, iyileşme çevresi, gereksinimlere yardım faktörlerine daha fazla önem verecekleri belirlenmiştir (Tablo 5).

İnanç-umut faktörüne göre; bireylerle doğal bir ilişki içinde olarak inanç ve umudu 
aşılama söz konusudur [20]. Emzirme annenin kendine güvenmesi ve bu konuda yeterli olduğunu düşünmesi çok önemlidir. Emzirmeyi başarabileceğine inanmalıdır. Çünkü emzirmede annenin öz-yeterliliği, olumlu emzirme sonuçlarıyla bağlantılıdır ve değiştirilebilir faktörlerden biridir [21]. Bu nedenle eğitimler sırasında annenin inanç ve umudunun desteklenmesi önemli bir etkiye sahiptir.

Olumlu ve olumsuz duyguların ifadesi faktörüne göre; bireylerin hikâyelerini içten samimi bir şekilde dinlemek çok önemlidir. Bu nedenle annelerin olumlu ve olumsuz duyguların ifade etmeleri sağlanmalıdır [20]. Başkalarının hikâyelerini dinlemek onlara için yapılan en iyi iyileştirme yöntemi olabilir [5]. Emzirme problemi yaşayan annelerin yaşadıkları duyguları ve deneyimleri belirlemek amacıyla yapılan bir çalışmada, annelerin duygularının sorulmadığı, kendilerini ifade edebilmek için fırsat verilmediği belirtilmiştir [22]. Emzirme eğitimlerinde annenin öyküsünü dinleyerek kendisini ifade etmesine izin verilmelidir. Böylece annenin gereksinimi olan konular belirlenerek daha etkin bir eğitim süreci sağlanabilir.

Öğretme-öğrenme faktörüne göre; bireysel intiyaçlara, hazır bulunuşluklara ve öğrenme stillerine hitap eden öğretim yolu seçilmelidir [20]. Leruth ve ark. [23] "emzirme her birey için farklıdır" diyerek prenatal dönemden postnatal 6. aya kadar devam eden bireysel emzirme eğitimi düzenlemişlerdir. Çalışma sonucunda doğum sonu annelerin çoğunun $(\% 67,0)$ bebeğini emzirdiği belirlenmiştir.

İyileşme çevresi faktörüne göre; zihinsel, fiziksel, sosyokültürel ve manevi olarak rahat ve huzurlu bir çevre sağlanmalıdır [20]. Watson'ın iyileştirici çevresini oluşturmak için; ışık gibi zararlı uyaranlar, gürültü ve dağınık yok edilmelidir. Bireylerin intiyaçları doğrultusunda egzersiz, derin nefes alma veya meditasyon gibi terapötik uygulamalar için alan oluşturulmalıdır. Mobilyalar düzenli olmalıdır, mahremiyete özen gösterilmelidir. Gereksinimlere göre sanat, müzik, şiir de kullanılabilir [24]. Emzirme eğitimlerinde annenin rahat ve huzurlu bir çevrede eğitim alıyor olması, kendisini daha rahat hissetmesini sağlayacaktır. Böylece anne duygularını daha kolay ifade edebilecek, odaklanma sorunu yaşamayacaktır ve eğitim daha verimli geçecektir.
Gereksinimlere yardım faktörüne göre; bireylerin fiziksel, duygusal ve ruhsal intiyaçlarına saygıyla yardım edilmelidir [20]. Doğum sonu dönemde annelerin bebeklerini sadece anne sütü ile beslemelerinde sağlık profesyonellerinin desteğinin önemli bir yeri vardır [25]. Powell ve ark.'nın [26] çalışmasında, sağlık profesyonellerinin doğum sonu emzirme konusunda annelerin çoğuna olumsuz destek ve yardımda bulunduğunu ya da hiç desteklemediği belirlenmiştir. Emzirme eğitimine olan intiyaç prenatal dönemde başlar ve postpartum dönemde devam eder. Bu nedenle annelerin döneme özgü gereksinimleri göz önünde bulundurularak eğitim ve danışmanlık hizmetleri sürdürülmelidir.

Kurs programının sadece kamu hastanelerinin gebe okulu/emzirme eğitimcileri için planlanmış olması çalışmanın sınırıığını oluşturmaktadır. Ayrıca doküman inceleme yönteminin sınırlılıklarından olan "yazılı bilgilere güvenmek" [27] maddesi de araştırmanın sınırlılığı olarak kabul edilebilir.

Sonuç olarak; emzirme eğitimcilerinin değerlendirme sonuçlarına bakıldığında Watson'ın İnsan Bakım Kuramına temellendirilmiş emzirme eğitiminin kurs katılımcılarının farkındalığını arttırdığı görülmüştür. Katılımcılar eğitim programlarına yenilikçi eğitim yöntemlerini ve İBK'nı dâhil etmeyi planladıkları belirlenmiştir. İBK'nın iyileştirme kavramlarını bundan sonra yürütecekleri eğitim programlarına dâhil edeceklerini belirtmeleri bu kavramları/faktörleri içselleştirdikleri ve benimsediklerini göstermektedir. Emzirme eğitimlerinde farklı teknolojilerin, yenilikçi yöntemlerin kullanıldığı yöntemler ebeveynlerin daha fazla ilgisini çekmektedir [28, 29]. Bu nedenle ebeveynlerin daha fazla ilgisini çeken ve yapılan eğitimlerin değerlendirilmesini sağlayan programlar planlanmalıdır. Programların etkinliğini değerlendirmek ve emzirme hedeflerine ulaşmak için ise eğitim programlarının oluşturulmasında kuram kullanımından yararlanılmalıdır.

Çıkar ilişkisi: Yazarlar çıkar ilişkisi olmadığını beyan eder.

\section{Kaynaklar}

1. Victora CG, Bahl R, Barros AJ, et al. Breastfeeding in the 21st century: Epidemiology, mechanisms, and lifelong effect. The Lancet 2016;387:475-490. 
2. Türkiye Nüfus ve Sağlık Araştırması 2018. Erişim adresi: http://www.hips.hacettepe.edu.tr/tnsa2018/ rapor/TNSA2018_ana_Rapor.pdf. Erişim tarihi 05 Haziran 2020

3. Lumbiganon $\mathrm{P}$, Martis R, Laopaiboon M, Festin MR, Ho JJ, Hakimi M. Antenatal breastfeeding education for increasing breastfeeding duration. Cochrane Database Syst Rev 2016;12:1-79. https://doi. org/10.1002/14651858.CD006425.pub4

4. Ozan YD, Okumuş $\mathrm{H}$. Tedavi sonucu başarısız olan infertil kadınların Watson'ın İnsan Bakım Kuramına göre hemşirelik bakımı. Anadolu Hemşirelik ve Sağlık Bilimleri Dergisi 2013;16:190-198.

5. Ozan YD, Okumuş $\mathrm{H}$. Effects of nursing care based on watson's theory of human caring on anxiety, distress, and coping, when infertility treatment fails: A randomized controlled trial. J Caring Sci 2017;6:95109. https://doi.org/10.15171/jcs.2017.010

6. Finfgeld Connett $D$. Meta-synthesis of caring in nursing. J Clin Nurs 2008;17:196-204. https://doi.org/10.1111/ j.1365-2702.2006.01824.x

7. Arslan Özkan İ, Okumuş H, Buldukoğlu K. A randomized controlled trial of the effects of nursing care based on Watson's Theory of Human Caring on distress, selfefficacy and adjustment in infertile women. J Adv Nurs 2014;70:1801-1812. https://doi.org/10.1111/jan.12338

8. Aktürk Ü, Erci B. The effect of Watson's Human Caring Model on meaning of life and symptom management in cancer patients undergoing chemotherapy. Res Theory Nurs Pract 2018;32:255-275. https://doi. org/10.1891/1541-6577.32.3.255

9. Watson J. Caring as the essence and science of nursing and health care. O Mundo Da Saude 2009;33:143-149.

10. Karaçam Z, Sağlık M. Emzirme sorunları ve sorunlara ilişkin yapılan girişimler: Türkiye'de yapılan çalışmalara dayalı bir sistematik derleme. Türk Pediatri Arş 2018;53:134-148. https://doi.org/10.5152/ TurkPediatriArs.2018.6350

11. Feenstra MM, Kirkeby MJ, Thygesen MK, Danbjørg DB, Kronborg H. Early breastfeeding problems: a mixed method study of mothers' experiences. Sex Reprod Healthc 2018:16;167-174. https://doi.org/10.1016/j. srhc.2018.04.003

12. Kellams AL, Gurka KK, Hornsby PP, et al. The impact of a prenatal education video on rates of breastfeeding initiation and exclusivity during the newborn hospital stay in a low-income population. J Hum Lact 2016;32:152159. https://doi.org/10.1177/0890334415599402

13. Adhisivam B, Vishnu Bhat $B$, Poorna R, Thulasingam $M$, Pournami F, Joy R. Postnatal counseling on exclusive breastfeeding using video-experience from a tertiary care teaching hospital, south India. J Matern Fetal Neonatal Med 2017;30:834-838. https://doi.org/1 $0.1080 / 14767058.2016 .1188379$
14. Karabay M, Kaya G, Caner İ, Karabay O. Yenidoğan yoğun bakım ünitesinde anne sütü ve hijyen eğitiminin yatan hasta memnuniyetine etkisi. Sakarya Tıp Derg 2019;9:695-699. https://doi.org/10.31832/smj.595338

15. Seven M, Bağcivan G, Kılıç S, Açıkel C. Hemşirelik yüksekokulu birinci sınıf öğrencilerinin öğrenme stillerinin belirlenmesi ve ders başarıları ile ilişkisinin incelenmesi. Gülhane Tıp Dergisi 2012;54:129-135. https://doi.org/10.5455/gulhane.19730

16. Saljughi F, Savabi Esfahani M, Kohan S, Ehsanpour S. Promoting breastfeeding self-efficacy through roleplaying in pregnant women. Int J Pediatr 2016;4:20612068. https://doi.org/10.22038/ijp.2016.7000

17. Ramsburg JT, Youmans RJ. Meditation in the higher-education classroom: Meditation training improves student knowledge retention during lectures. Mindfulness 2014;5:431-441. https://doi. org/10.1007/s12671-013-0199-5

18. Akarsu RH, Tunca B, Alsaç SY. Anne-bebek bağlanmasında kanıta dayalı uygulamalar. GÜSBD 2017;6:275-279.

19. Perez Blasco J, Viguer P, Rodrigo MF. Effects of a mindfulness-based intervention on psychological distress, well-being, and maternal self-efficacy in breast-feeding mothers: results of a pilot study. Arch Womens Ment Health 2013;16:227-236. https://doi. org/10.1007/s00737-013-0337-z

20. Garrett, B. Unitary caring science: The philosophy and praxis of nursing Jean Watson University Press of Colorado, Louisville. Nurs Philos 2018;20:1-204. https://doi.org/10.1111/nup.12227

21. Piro SS, Ahmed HM. Impacts of antenatal nursing interventions on mothers' breastfeeding self-efficacy: an experimental study. BMC Pregnancy Childbirth 2020;20:1-19. https://doi.org/10.1186/s12884-0192701-0

22. Durmazoğlu G, Yenal K, Okumuş H. Maternal emotions and experiences of mothers who had breastfeeding problems: A qualitative study. Res Theory Nurs Pract 2020;34:3-20. https://doi.org/10.1891/15416577.34.1.3

23. Leruth C, Goodman J, Bragg B, Gray D. A multilevel approach to breastfeeding promotion: Using healthy start to deliver individual support and drive collective impact. Maternal Child Health J 2017;21:4-10. https:// doi.org/10.1007/s10995-017-2371-3

24. Carson EM. Do performance appraisals of registered nurses reflect a relationship between hospital size and caring? Nurs Forum 2004;39:5-13. https://doi. org/10.1111/j.0029-6473.2004.00005.x

25. Aktaş S, Kuroğlu ZÖ, Kazancı E, Korkmaz A. Bebek dostu bir hastanede doğumu takiben formül süt desteği verilmesinde belirleyici faktörler. Pam Tıp Derg 2020;13:81-90. https://dx.doi.org/10.31362/ patd.631449 
26. Powell R, Davis M, Anderson AK. A qualitative look into mother's breastfeeding experiences. J Neonatal Nurs 2014;20:259-265. https://doi.org/10.1016/ jnn.2014.04.001

27. Bensley RJ, Hovis A, Horton KD, et al. Accessibility and preferred use of online web applications among WIC participants with internet access. J Nutr Educ Behav 2014;46:87-92. https://doi.org/10.1016/j. jneb.2014.02.007

28. Durmazoğlu G, Okumuş H. Yenilikçi ve güncel eğitim yöntemlerinin kullanıldığı emzirme eğitimlerinin incelenmesi. Samsun Sağlık Bilimleri Dergisi 2019;4:23-31.

Etik kurul onayı: Dokuz Eylül Üniversitesi Girişimsel Olmayan Klinik Araştırmalar Etik Kurulu'ndan 01/06/2020 tarih ve 2020/11-48 karar numara ile etik kurul izni alınmıştır.

\section{Yazarların makaleye olan katkıları}

H.O. ve G.D. çalışmanın ana fikrini ve hipotezini kurgulamışlardır. H.O., M.A.T. ve Ö.Ç. teoriyi geliştirmiş ve gereç ve yöntem bölümünü düzenlemişlerdir. G.D. ve S.Y.T. verileri toplamışlardır. Sonuçlar kısmındaki verilerin değerlendirmesini H.O. ve G.D. yapmışlardır. Makalenin tartışma bölümü M.A.T., G.D, Ö.Ç ve S.Y.T. tarafından yazılmış, H.O. gözden geçirip gerekli düzeltmeleri yapmış ve onaylamıştır. Ayrıca tüm yazarlar çalışmanın tamamını tartışmış ve son halini onaylamıştır. 